- определение склонности субъекта деятельности к определенным типам лени;

— определение проблемных «зон» личности, способных детерминировать проявления лени того или иного типа;

- профилактика снижения эффективности трудовой и учебной деятельности на основе работы с проблемными «зонами»;

- профилактика эмоционального и профессионального выгорания за счет актуализации интраиндивидуальных ресурсов субъекта деятельности.

$$
\text { *** }
$$

1. Водопьянова Н. Е. Ресурсное обеспечение противодействия профессиональному выгоранию субъектов труда (на примере специалистов «субъект-субъектных» профессий) : автореф. дис. ... канд. психол. наук / Н. Е. Водопьянова. - СПб., 2014. - 48 с.

2. Леонгард К. Акцентуированные типы личности // Издательский дом: Феникс, 2000 г. - 448 с.

3. Личко А.Е. // Психиатрия // Изд.: «МЕДпресс-информ» Москва, 2006 г. - 416 с.

4. Лобанова Ю.И. К анализу физиологических и психологических основ лени (тезисы доклада) // Доклады 57-ой научной конференции профессоров, препод., научн. работников, инженеров и аспирантов, СПбГАСУ, ч.2, 2000г. С. 73-76

5. Маркова Е.Д., Лобанова Ю.И. Об изучении типов лени и их связей с особенностями волевой саморегуляции личности Тенденции развития науки и образования. 2020. № 61-9. С. 60-67.

6. Мусаниф С. // Во имя рейтинга // Издательство: Альфа-книга, Армада, 2006 г. - 74 с.

7. Никифоров Г. С. Надежность профессиональной деятельности / Г. С. Никифоров. - СПб. : Изд-во СПбГУ, 1996. - $176 \mathrm{c}$.

8. Осипова Л. В. Социально-психологические методы исследования личности и малых групп : учеб. пособие / Л. В. Осипова [и др.]. - СПб. : СПбГАСУ, 2013. - 120 с.

9. Посохова С.Т. Лень: психологическое содержание и проявления // Вестник Санкт-Петербургского университета. Менеджмент. 2011. № 2. С. 159.

10. Практическая психология для экономистов и менеджеров / учеб. пособие для вузов / под ред. М.К. Тутушкиной. - СПб.: Изд-во «Дидактика Плюс», 2002. -365 с

11. Психологическое обеспечение профессиональной деятельности: учеб. пособие/С. А. Боровикова, Т. П. Водолазская, М. А. Дмитриева, Л. Н. Корнеева; Ред. Г. С. Никифоров; СПбГУ. -СПб.: Изд-во СПбГУ, 1991. -152 с.

12. Рубинштейн С.Л. // Основы общей психологии // Издательство: Питер, 2002 г. - 720 с.

13. Смулевич А.Б.//Депрессии в общей медицине Руководство для врачей // М., Медицинское информационное агентство, 2001 г. - 782 с.

14. Толочек В.А. Стили деятельности: ресурсный подход. - М.: Изд-во "Институт психологии РАН", 2015. - $366 \mathrm{c}$.

15. Фьоре Н. Легкий способ перестать откладывать дела на потом // Манн, Иванов и Фербер; Москва; 2013 г. -288 с.

16. Справочная информация: "Профессиональные стандарты и квалификации" Labor psychology, engineering psychology,http://www.consultant.ru/document/cons_doc_LAW_157436 ergonomics / (дата обращения - 3 декабря 2019).

\title{
Макова М.И. \\ Медиакомпетентность как актуальное требование к подготовке современного педагога-психолога
}

ТИ имени А.П. Чехова (филиал) «РГЭУ (РИНХ)»

(Россия, Таганрог)

doi: $10.18411 / l j-02-2021-190$

idsp: ljournal-02-2021-190

\section{Аннотация}

Анализ современного состояния образования в России и за рубежом показывает, что деятельность педагога-психолога все в большей степени включает использование медиа как профессионального инструмента, средства достижения целей образования. В этой связи возникает необходимость формирования медиакомпетентности педагогапсихолога, на что указывают ряд исследователей (А.А. Кузнецова, С.А. Бешенкова, 
Л.В. Галыгина, С. Григорьева, А. Лесневский, Е.А. Ракитина, Е.В. Лунев, К. Фомичев и другие. По мнению многих ученых, А.А. Андреева, Ю.С. Брановский, К. Колина, А. Могилев, Е.А. Ракитина, Е. Полат, О.К. Филатова и др.). Медиаобразование в современном мире перестает быть этапом в начале самостоятельной жизни и становится непрерывным процессом, сопровождающим человека в течение всей жизни. В настоящей статье обоснована необходимость формирования медиакомпетентности педагога-психолога, в вязи с динамичностью информационной и образовательной среды постоянное возникновение в них тех или иных изменений, которые требуют от психолога решения новых видов задач и, соответственно, включения в медиакомпетентность новых знаний, умений, навыков.

Ключевые слова: компетенция, медиакомпетентность, электронные образовательные ресурсы.

\section{Abstract}

The analysis of the current state of education in Russia and abroad shows that the activity of a teacher-psychologist increasingly includes the use of media as a professional tool, a means of achieving educational goals. In this regard, there is a need to form the media competence of a teacher-psychologist, as indicated by a number of researchers (A. A. Kuznetsova, S. A. Beshenkova, L. V. Galygina, S. Grigorieva, A. Lesnevsky, E. A. Rakitina, E. V. Lunev, K. Fomichev and others. According to many scientists, A. A. Andreeva, Yu. S. Branovsky, K. Kolina, A. Mogilev, E. A. Rakitina, E. Polat, O. K. Filatova et al.). Media education in the modern world ceases to be a stage at the beginning of independent life and becomes a continuous process that accompanies a person throughout life. In this article the necessity of formation of media competence of a teacher-psychologist, in regards to dynamic information and educational environment of constant occurrence in them of certain changes that require the psychologist to address new types of problems and therefore, inclusion in media competence new knowledge and skills.

Keywords: competence, media competence, electronic educational resources

Все мы живем в эпоху информационного общества, то есть в обществе, где большинство людей вовлечены в производство, хранение, обработку и внедрение информации, особенно ее высшей формы - знания.

Для успешного самообучения специалист должен обладать рядом умений и навыков, в том числе информационной грамотностью. Информация и все, что с ней связано, играет и будет играть решающую роль во всех жизненных ситуациях в современном мире. В настоящее время ПК является наиболее оптимальным технологическим средством получения информации. Используя реальные информационные технологии (электронная почта, СМИ, Интернет), формируются навыки анализа и отбора необходимой информации, систематизации, преобразования, хранения и передачи.

Информация - это ресурс с разными определениями в зависимости от формата и среды, используемой для его передачи, и в зависимости от области информации, в которой используется данное определение.[4]

В отчете Департамента информационной грамотности Университета штата Калифорния за 2001 год об информационной компетенции Университета штата Калифорния информационная компетенция представлена как компетенция библиотечных ресурсов, то есть компетенция связанная с поиском и обработкой различных фактов [2].

C.В. Тришина считает, что информационная компетентность - это «интегративное качество человека, которое является результатом отражения процессов 
отбора, усвоения, обработки, преобразования и генерации информации в особый тип предметно-специфических знаний, позволяющий развивать , сферы деятельности » [3].Информационное обучение необходимо для педагога-психолога. Использование ИКТ для проведения информационной деятельности и информационного взаимодействия между психологами из разных учреждений и не только. Т.Е. Захарова, И.В. Роберт под информационной деятельностью понимают деятельность по сбору, обработке, использованию, производству, передаче и тиражированию информации в образовательной и профессиональной деятельности, при условии внедрения навыков ИКТ.

Теоретико-методологический подход к реализации информационного обучения отражен в трудах и учебниках А.А. Кузнецова, С.А. Бешенкова, Л.В. Галыгина, С. Григорьева, А. Лесневский, Е.А. Ракитина, Е.В. Лунев, К. Фомичев и другие. По мнению многих ученых, А.А. Андреева, Ю.С. Брановский, К. Колина, А. Могилев, Е.А. Ракитина, Е. Полат, О.К. Филатова и др.

В контексте компьютеризации общества современные информационные и коммуникационные технологии составляют технологическую основу для создания информационной и образовательной среды. Таким образом, современные ИКТ обновляют процесс расширения информационного поля.

Однако одних знаний в области ИКТ современному педагогу-психологу в настоящее время недостаточно. Для продуктивного выполнения своих профессиональных обязанностей ему необходимо быть медиакомпетентным. И.В.Челышева отмечает, что «медиакомпетентность выступает одной из ключевых компетенций будущего педагога-психолога, которому предстоит осуществлять свою профессиональной деятельность с подрастающим поколением, для которого медиапространство стало привычной средой обитания. Развитие медиакомпетентности осуществляется в медиаобразовательном процессе, которое все активнее реализуется в современном образовании путем интеграции в учебные дисциплины, включением в разные виды внеурочной деятельности, приобщения к медиатворчеству и т.д.» [10].

В.А. Сластенин рассматривает понятие «компетентность» как неотъемлемую черту деловых и личных качеств специалиста, отражая не только уровень знаний, навыков, опыта, достаточный для достижения целей профессиональной деятельности, но и социально-моральное положение личности[5, с. 57]. Что касается медиакомпетентности, то данное понятие в настоящее врем включает в себя умение «ориентироваться в условиях переизбытка разнообразной информации, грамотно воспринимать ее, понимать, анализировать, иметь представление о механизмах и последствиях ее влияния на зрителей, читателей и слушателей. В свободном демократическом обществе на первое место выходит способность и готовность оценивать ситуацию самостоятельно, без предубеждения, распознавать приемы психологического манипулирования в медийном пространстве» [9, с. 12].

Последние годы проблемам медиакомпетентности в педагогическом сообществе посвящены труды Ю.С.Тюнникова, И.С.Казакоав, М.А. Мазниченко, А.М.Мамадалиева [7], А.В. Федорова, И.В.Челышевой, Е.В.Мурюкиной и др. [8; 9; 10]

Управленческая цель педагога-психолога - создание психолого-педагогических условий, направленных на развитие социально адаптированной личности. Образовательная цель - способствовать личностному и интеллектуальному развитию детей на всех этапах возрастного развития. А так как все сферы жизни современного подрастающего поколения так или иначе связаны с медиакультурой, профессиональное становление педагога-психолога невозможно рассматривать без подготовки к медиаобразовательному процессу. 
Сопоставим направления работы педагога-психолога с основными положениями медиакомпетентности.

Коррекционно - развивающее направление работы подразумевает умение осуществлять поиск путей и методов медиаобразования, способствующих развитию познавательных, интеллектуальных, творческих интересов и способностей подрастающего поколения. Для успешной реализации научно - методического направления необходимо развитие поисковых и аналитических умений, которые, как известно. имеют ключевую роль в работе с медиатекстами.

Консультативно - просветительское направление требует овладение передовыми методиками и технологиями медиаобразования и их использования в психологопедагогической деятельности.

Профилактическое направление напрямую связано и оценочным показателем медиакомпетентности, который включает в себя умение осуществлять анализ, синтез и рефлексию по отношению к медиатекстам. Так, например, известно, что «просмотры и коллективные обсуждения экранных медиатекстов (фильмов, телепередач, интернетных сайтов) способствуют созданию творческой атмосферы на занятиях, развитию критического мышления и умению аргументированно оценивать медиаинформацию» [10].

Педагог-психолог должен быть медиакомпетентным специалистом, уметь работать с медиаинформацией вне зависимости от используемых средств доступа к ней, ее обработки, хранения и распространения, так как «необходимость подготовки педагогов школ и вузов к осушествлению деятельности на материале произведений медиакультуры обусловлена велением времени. Стратегия модернизации отечественного образования направлена на развитие ключевых компетенций в интеллектуальной, общественно-политической, коммуникационной, информационных сферах. Компетентностный подход, акцентирующий внимание на результативности образования, заключается не в определенной сумме приобретенных студентом знаний или количестве усвоенной информации, а в способности действовать в различных проблемных ситуациях, осуществляя поиск, отбор и анализ информации. Поэтому в настоящее время педагогам для успешного осуществления профессиональной деятельности необходимы не только знания по теории и методике преподавания учебных предметов, педагогике и психологии, но и умения работать с медиаинформацией» [9].

Рассмотрев профессиональную деятельность психолога-педагога, мы видим, что какую бы профессиональную задачу он перед собой не ставил, все они так или иначе в современных условиях связаны с медиасферой. Медиакомпетентность педагогапсихолога заключается в умениях выбрать из потока достоверную информацию, грамотно переработать ее с учетом стоящих перед ним профессиональных задач, уметь использовать информационные модели для описания психолого-педагогических объектов и явлений.

Профессиональная деятельность педагога-психолога включает в себя умение системно работать с видео- и аудиоинформацией, правильную самоидентификацию, полноценный анализ, грамотную обработку и передачу этой информации. Это особенно важно в современном информационном обществе, когда информация хранится в большей степени в электронном виде, а компьютер предлагается в качестве помощника для самоидентификации во всем разнообразии информации во всех сферах жизни. Именно поэтому педагог-психолог должен быть медиаграмотным, медиакомпетентным специалистом, что подразумевает его способность работать с любой информацией, используя потенциал медиакультуры для образования и развития подрастающего поколения. Особую актуальность медиакомпетентность приобретает в 
профессиональной деятельности, связанной с психологической направленностью деятельности педагога-психолога. Сюда включаются умения использовать информационные модели для описания изучаемых психологических объектов и явлений; владеть компьютерными методами сбора, хранения и статистической обработки результатов психологического эксперимента и т. д.

Эти навыки играют важную роль в росте психолога как специалиста, который затем может участвовать в различных конкурсах, где одним из требований является умение работать с различными компьютерными программами, умение представить свою информацию.

Итак, резюмируя вышесказанное, можно сказать, что информационная грамотность имеет множество определений, существует несколько трактовок этого понятия. Профессиональная деятельность психолога - это деятельность, включающая в себя умение целенаправленно работать с информацией, правильную идентификацию, обработку, хранение, передачу. Это особенно важно в современном информационном обществе, когда информация в основном хранится в электронном виде, а компьютер действует как помощник для ориентации во всем разнообразии доступной информации.

На основании теоретического анализа данной проблемы можно сделать вывод: информационная компетентность человека является системным строителем, так как именно уровень владения этой компетентностью определяет уровень владения человеком всеми ключевыми компетенциями.

$$
* * *
$$

1. Богачева Л. С. Компетентность и компетенция как понятийно-терминологическая проблема / Л. С. Богачева // Актуальные вопросы современной педагогики: материалы II междунар. науч. конф. (г. Уфа, июль 2012 г.). - Уфа: Лето, 2012.

2. Павлюк Р.А. Генезис понятия «информационная компетентность» в контексте непрерывного педагогического образования // Гуманитарные научные исследования. 2014. № 1 [Электронный pecypc]. URL: http://human.snauka.ru/2014/01/5529 дата обращения: 29.12.2020

3. Руководство по информационной грамотности для образования на протяжении всей жизни / Guidelines on Information Literacy for Lifelong Learning / Александр Федоров, научное редактирование перевода, 2007: Издатель МОО ВПП ЮНЕСКО «Информация для всех».

4. С.В. Тришина, А.В. Хуторской Информационная компетентность специалиста в системе дополнительного профессионального образования / Интернет-журнал «Эйдос». 2004. URL// http://www.eidos.ru/journal/2004/0622-09.htm.

5. Сластенин В.А., Педагогика: Учеб. пособие для студ. высш. пед. учеб. заведений / В.А.Сластенин, И.Ф.Исаев, Е.Н.Шиянов; Под ред. В.А.Сластенина. - М.: Издательский центр «Академия», 2002. $576 \mathrm{c}$.

6. Тришина С.В., Хуторской А.В., Информационная компетентность специалиста в системе дополнительного профессионального образования / Интернет-журнал «Эйдос». 2004. [Электронный ресурс] Режим доступа:// http://www.eidos.ru/journal/2004/0622-09.htm.

7. Тюнников Ю.С., Казаков И.С., Мазниченко М.А., Мамадалиев А.М. Медиакомпетентность педагога: инновационный подход к самопроектированию // Медиаобразование. 2016. №4. URL: https://cyberleninka.ru/article/n/mediakompetentnost-pedagoga-innovatsionnyy-podhod-ksamoproektirovaniyu (дата обращения: 12.01.2021).

8. Федоров А.В., Челышева И.В. и др. Массовое медиаобразование в СССР и России. М. - Берлин: Директ-медиа, 2020.375 с.

9. Челышева И.В. Медиаобразовательный компонент в работе учителя школы и преподавателя вуза: возможности реализации // Знак: проблемное поле медиаобразования. 2016. №4 (21). URL: https://cyberleninka.ru/article/n/mediaobrazovatelnyy-komponent-v-rabote-uchitelya-shkoly-iprepodavatelya-vuza-vozmozhnosti-realizatsii (дата обращения: 12.01.2021).

10. Челышева И.В. Медиаобразовательные технологии в формировании межкультурной компетенции будущих педагогов-психологов // Актуальные проблемы теории и практики психологических, психолого-педагогических и педагогических исследований [Электронный ресурс] : Сборник трудов Международной научно практической конференции Левитовские чтения» (г. Москва, 15 16 апреля 2020 г.) : в трёх томах / /ред. колл.: Т. С. Комарова (отв. ред.), Т. Н. Мельников, В. К. Виттенбек, А. С. Москвина и др. - Электрон. текстовые дан. - М.: Перо, 2020. С.990-995. 